\title{
Cuban Meningococcal BC Vaccine: Experiences \& Contributions from 20 Years of Application
}

\author{
Franklin Sotolongo Padrón, MD, Concepción Campa Huergo, PhD (h.c.), Victoria Casanueva Gil, MD, \\ Esther María Fajardo Díaz, MSc, Iván Edelberto Cuevas Valdespino, MD, MSc, Noel González Gotera
}

\begin{abstract}
This paper reviews 20 years of experience and scientific contributions of the Cuban meningococcal BC vaccine (VA-MENGOC-BC ${ }^{\circledR}$ ) obtained by the Finlay Institute in Havana, Cuba. The vaccine is the first of its type in the world that is safe, effective, and commercially available for preventing meningococcal disease caused by serogroup $B$ meningococcus; it is also effective against serogroup C. VA-MENGOC-BC ${ }^{\circledR}$ has shown satisfactory results, with no serious adverse events, after application of approximately 55 million doses in some 15 countries. Also included is background information on meningococcal disease, as well as the main characteristics of $\mathrm{VA}-\mathrm{MENGOC}-\mathrm{BC}^{\circledR}$, the strategy used for controlling meningococcal disease and its prevention in Cuba, and a summary of the main scientific results obtained in basic research, development, clinical evaluation, and post-marketing results (safety, efficacy-effectiveness, post-vaccination adverse events, etc.) in Cuba and elsewhere.
\end{abstract} cine; serogroup B meningococcus; serogroup C meningococcus; VAMENGOC-BC ${ }^{\circledR}$
Key Words: Meningitis; meningococcal disease; meningococcal vac-

observation was revised due to outbreaks in Europe and North America. Since World War II, the main meningococcal epidemics have been in SubSaharan countries, including a vast territory called the Meningitis Belt, extending to a significant number of countries from The Gambia to Sudan, where $60 \%$ to $65 \%$ of all meningitis cases reported correspond to meningococcal meningitis.[2]

Clinically, meningococcal disease presents in two basic forms: meningitis and meningococcemia (septicemia), the latter being the most severe form. Meningococci are generally located in the upper respiratory tract. In most cases, they colonize the nasopharyngeal mucosa asymptomatically and the affected person becomes a healthy nasopharyngeal carrier. Bacteria are spread from person to person mainly by droplets of oropharyngeal and respiratory secretions or directly through saliva. Infection arises when the bacteria reach and adhere to the epithelial cells of the receptor's nasopharyngeal mucosa. The bacteria can then pass through the bloodstream to lodge in the central

\section{MENINGOCOCCAL DISEASE}

According to the World Health Organization (WHO), approximately 500,000 bacterial meningitis cases are detected each year, resulting in 50,000 deaths. Three bacterial species, Haemophilus influenzae type b, Streptococcus pneumoniae, and Neisseria meningitidis are responsible for the majority of cases reported.[1]

Meningococcal disease is caused by $N$. meningitidis, a Gramnegative bacterium known as meningococcus, for which humans are the only natural reservoir. This bacterium is coated with a polysaccharide capsule (of great antigenic importance) that can vary in chemical constitution, resulting in its classification into 13 different serogroups. The most important of these - A, B, C, Y, and $W_{135}$ - produce most of the clinical infections and disease outbreaks. Furthermore, serogroups A, B, and C meningococci are the main cause of meningococcal epidemics and represent more than $90 \%$ of the thousands of cases reported each year. Of these, $5 \%$ to $10 \%$ are fatal in developed countries, with a higher mortality in developing countries. Moreover, $10 \%$ to $20 \%$ of survivors develop permanent sequelae such as epilepsy, mental retardation, or sensorial deafness. Meningococcal disease is a global problem, affecting countries regardless of climate or development. It is characterized as the cause of epidemic meningitis; secondary cases come from an index case, with the probability of forming groups or local outbreaks.[2]

In the 60s, meningococcal disease was considered a significant health problem in certain tropical countries, but in the 70s that nervous system, reaching the surrounding meningeal membranes and cerebrospinal fluid, developing a severe infection that occasionally presents a fulminant evolution. In some cases, death can follow within a few hours.[2]

The nasopharyngeal carrier status is much more frequent than the meningococcal disease itself, and is the most common source of new infections. Among adolescents, $15 \%-25 \%$ may be carriers; in the general population, $2 \%-15 \%$ are carriers. Children under 5 are most frequently affected by the disease, the highest incidence occurring in infants aged 6-12 months. Other important risk groups are adolescents, young adults, and people living in close quarters, such as boarding schools, military bases, and prisons.[2]

Treatment is based on antibiotics, but the most effective action to fight an epidemic outbreak is vaccination of high-risk populations.

\section{MENINGOCOCCAL DISEASE IN CUBA}

From 1916 to 1975, meningococcal disease took an endemic form, with 10 to 40 sporadic cases annually. However, in May 1976, an epidemic began as household outbreaks, later growing to unprecedented proportions for Cuba, with general incidence increasing by $50 \%$ (from 0.4 to 0.8 per 100,000 population). In response, the Ministry of Public Health reinforced epidemiological surveillance. In 1978, the incidence increased to 1.5 per 100,000 population, and in 1979 reached 5.6 per 100,000 population. Predominant serogroups were C (50\% of recorded cases) and B (35\%). The most affected age group 
was 10- to 14-year olds, followed by infants under one. That year, individuals between 3 months and 19 years of age $(3,245,046$ people) were immunized, using a commercially available polysaccharide AC vaccine (Mérieux, France). Coverage during that campaign was $80 \%$, and the number of cases due to serogroup $\mathrm{C}$ was substantially reduced.[3]

Nevertheless, incidence of the disease continued to rise over the next few years, the prevalent serogroup changing to $B$ (78.4\% of cases). As a result, in 1980, meningococcal disease was considered the main health problem in Cuba, with incidence reaching 5.9 per 100,000 population, mortality running high. During 1983 and 1984, meningococcal disease reached a general incidence of 14.4 per 100,000 population, but in specific age groups - such as infants under one year - it was extraordinarily high, surpassing 120 per 100,000 population.

A review prepared by Valcárcel et al.[3] thoroughly describes the history of meningococcal disease in Cuba.

\section{CUBAN MENINGOCOCCAL BC VACCINE (VA-MENGOC-BC ${ }^{\circledR}$ )}

The Cuban government and Ministry of Public Health tackled the epidemic by strengthening the Epidemiological Surveillance Program for Meningococcal Disease, extending it to all infectious neurological syndromes. A study was initiated of meningococcal carriers in the Cuban population, and in 1983 , the important decision was made to establish a research team to develop an effective and safe vaccine against serogroup $B$ meningococcus. At the time, there were polysaccharide vaccines against serogroups $A, C, Y$, and $W_{135}$ available, but none for serogroup $B$. Because of the similarity between polysaccharide $B$ and molecules found in the human body, it had not been possible to use capsular polysaccharide purification technology to produce a vaccine against serogroup $B$ meningococcus. Several research teams around the world were working on this, but had been unable to obtain a licensed, marketable vaccine for serogroup B.[3]

After nearly 6 years of investigation that included basic research as well as pharmacological, preclinical, and clinical trials (Phases I, II, and III), followed by phased scaling up of the manufacturing process, researchers and technicians produced a vaccine candidate. This candidate was based on purified proteins from the outer membrane of $a$ serogroup B strain, plus a purified capsular polysaccharide from a serogroup $C$ meningococcus strain.

Once all phases of the preclinical and clinical trials were successfully completed and the safety and efficacy of the product demonstrated, $[3,4]$ the national regulatory authority - Government Center for Quality Control of Medicines (CECMED) under the aegis of the Ministry of Public Health - licensed the vaccine for use in Cuba[5]. It was registered under the trade name VA-MENGOC-BC ${ }^{\circledR}$. In 1989, the Cuban Intellectual Property Office (OCPI) granted a patent on the product.[6] That same year, the United Nations' World Intellectual Property Organi- zation (WIPO) awarded its Gold Medal to the Cuban meningococcal $B C$ vaccine, in recognition of the global innovation represented by the product. Patents were later extended to the vaccine by the European Union[7] and United States,[8] among others.

Since then, more than 55 million vaccine doses have been administered in Cuba and 15 other countries, primarily in Latin America and the Caribbean. The vaccine has been found safe, with no reports of adverse post-vaccination events of consequence,[4,9-11] and has proven effective in controlling several epidemics.[12-21]

\section{CUBA'S VA-MENGOC-BC ${ }^{\otimes}$ STRATEGY \\ TO COMBAT MENINGOCOCCAL EPIDEMICS}

The Cuban Ministry of Public Health's strategy was carried out in 2 stages. The first was a nationwide mass vaccination campaign carried out from 1989 to 1990 targeting the high risk population aged 3 months to 24 years, involving over 3 million people and achieving a general coverage of 95\%.[3] The main objective of this stage was to halt the increase in the incidence of the disease. The second stage, begun in 1991 and continuing to date, included VA-MENGOC-BC ${ }^{\circledR}$ in the National Immunization Program, using a 2-dose schedule: the first dose at 3 months and the second at 5 months of age. The objective of this stage was to protect all children born after the mass vaccination campaign, in order to prevent new epidemic outbreaks over time among an accumulated susceptible population.

This strategy proved correct (Figure 1). The mass vaccination campaign and subsequent immunization of all later newborns, has resulted in a sharp and sustained decline in general incidence of the disease, reaching 0.2 per 100,000 population as of December 2006, a lower incidence than that reported at the epidemic's outset (0.4 per 100,000 population).
FIGURE 1: General Incidence of Meningococcal Disease in Cuba after Vaccination: 1989-2006

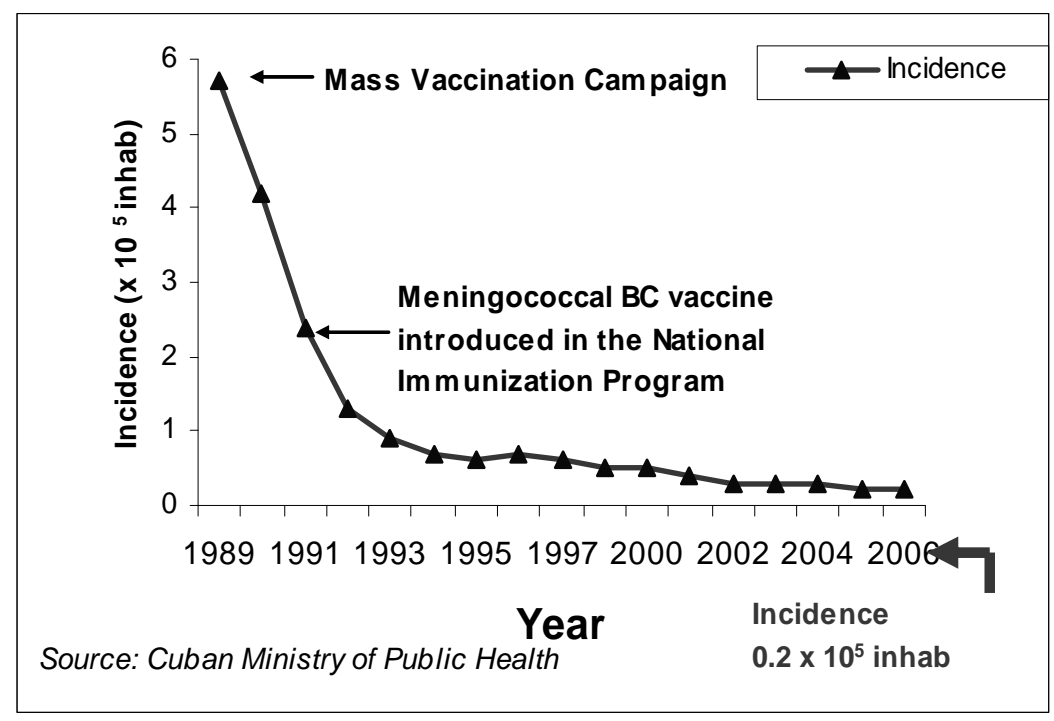




\section{VACCINE CHARACTERISTICS}

VA-MENGOC-BC ${ }^{\circledR}$ is an injectable suspension for intramuscular use. Each $0.5 \mathrm{~mL}$ dose contains $50 \mu \mathrm{g}$ of outer membrane vesicles (OMVs) from serogroup $B$ meningococcus (B:4:P1.19,15:L3,7,9 strain) and $50 \mu \mathrm{g}$ of the purified capsular polysaccharide of meningococcal serogroup (C C11 strain), adsorbed onto an aluminum hydroxide gel $(2.0 \mathrm{mg})$ as adjuvant. The vaccine also contains thimerosal $(0.05 \mathrm{mg})$ as preservative, disodium hydrogen phosphate $(0.03 \mathrm{mg})$, dehydrated sodium dihydrogen phosphate $(0.302 \mathrm{mg})$, sodium chloride $(4.25 \mathrm{mg})$, and enough water for injection to complete volume. The vaccine is available in 1,10, and 20-dose ampules. Manufacturing is carried out according to strict quality assurance and control protocols from raw materials to final product, complying with Standard Operating Procedures (SOPs) based on good manufacturing and laboratory practices, including appropriate certification of technical and laboratory equipment used throughout production. This ensures quality and consistency of the vaccine lots produced.

\section{VACCINE SAFETY}

During the various stages of research and development, all phases of clinical trials for the vaccine's safety evaluation were strictly followed, in accordance with international guidelines and ethical standards.

At the beginning of 1985 , a Phase I trial was conducted in adult volunteers to assess the safety of the vaccine candidate. The results indicated that adverse effects were limited to a rise in body temperature to $99.5^{\circ} \mathrm{F}\left(37.5^{\circ} \mathrm{C}\right), 6$ to 15 hours postvaccination, and to slight pain at the injection site - similar to that produced by the tetanus vaccine. That year, several Phase II trials were conducted with volunteers to evaluate safety and immunogenicity, and to define inter-dose period. Pain at the injection site and slight fever were the most frequent adverse effects. In a clinical trial with children aged 6 months to 12 years, there was slight pain at the injection site and erythema; no fever was observed in the vaccinees.[3]

In a Phase III safety trial, a sub-sample was analyzed consisting of 2,072 vaccinees from among 105,251 participating adolescents. Results showed discrete predominance of local symptoms (56\%) over general (44\%). Most important general symptoms were headache, general discomfort, nausea, and fever; local symptoms were mainly induration, redness, and pain at the injection site.[3,12]

After the product was licensed for use, several Phase IV (postlicensing) studies were carried out in Cuba and other countries where the vaccine has been administered.[4,9,13,14,16-25]

Since VA-MENGOC-BC ${ }^{\circledR}$ has been administered consistently in Cuba since 1991 in the National Immunization Program, a retrospective study was conducted in 1998 to explore adverse effects. The research was carried out in three municipalities in Havana City, using the clinical records of children vaccinated between October 1990 and February 1998. The total sample consisted of 12,822 children, aged 3-5.5 months. The adverse effects detected were similar to those described above, and they all disappeared within the first 72 hours post-vaccination.[4]
In Brazil, where the vaccine has been most widely administered in mass vaccination campaigns, an analysis was published in the Manual for Surveillance of Adverse Effects by the National Health Foundation, based on studies carried out on the vaccination of more than 9 million people, in which the vaccine was considered of slight reactogenicity and well tolerated.[9]

In Argentina, active observations were carried out during the vaccination campaigns using VA-MENGOC-BC ${ }^{\circledR}$ in adults, revealing that most reactions observed were local.[10]

In Uruguay, the vaccine was administered to control a meningococcal disease outbreak caused by serogroup B. The active surveillance of 728 subjects aged 2-19 years showed no adverse effects in $47 \%$ of the vaccinees. Of the rest, $71 \%$ of the events were local reactions, the remainder general reactions. Local pain (55\%) and general discomfort (30\%) were the most frequent reactions.[11]

Over 55 million doses of the vaccine have been administered with rare serious adverse effects (anaphylactic shock, hypotonic hypo-responsive episodes, angioneurotic edema): fewer than 1 per million doses administered.

\section{VACCINE IMMUNOGENICITY}

In studies on meningococcal vaccines of polysaccharide origin, evidence of bactericidal activity against meningococcus in serum samples of an individual is regarded as a protective condition against that bacterium. As a result, the Serum Bactericidal Assay (SBA) is considered the "gold standard" for their evaluation,[25] but it tends to underestimate the values of vaccines containing other components, such as those with outer membrane proteins of serogroup B meningococcus.[26] This has led to the use of other immunobiological assays, such as the Whole-Blood Bactericidal Assay (WBBA) or the Whole-Blood Lysis[27] that reproduce the bacteremia and attendant defense mechanisms in vitro, including antibodymediated lysis, the complement system, and opsonophagocytosis. Immunoenzymatic techniques (ELISA) are also used to detect high avidity antibodies, due to their simplicity for multiple sample assessment.[28]

Immunogenicity studies carried out with VA-MENGOC-BC ${ }^{\circledR}$, and evaluated by the above mentioned techniques, have demonstrated the ability of the vaccine to stimulate specific protective antibodies. Clinical trials conducted in Cuba and other countries show an immune response elicited by the vaccine through the induction of specific antibody levels and serum bactericidal activity against strains of serogroups $B$ and $C$ in the vaccinees (Tables 1 and 2).

In VA-MENGOC-BC ${ }^{\circledR}$, the $\mathrm{C}$ polysaccharide component is attached to proteins; although this is not a covalent bond, this seems to favor its presentation to the immune system, thus contributing to a better immune response.

Among the published immunogenicity studies, the clinical trial in Iceland carried out by Perkins et al.[21] in young adults, shows an immune response against the vaccine strain and other het- 
Table 1: Results of Studies Conducted in Cuba on the Immune Response Induced by the $\mathrm{B}$ Component of VA-MENGOC-BC ${ }^{\circledR}$

\begin{tabular}{|l|l|c|c|c|c|}
\hline & Group & \multicolumn{2}{|l|}{$\begin{array}{l}\text { Serum Bactericidal Assay } \\
\text { B:4:P1.19,15 } \\
\text { Vaccine Strain }\end{array}$} & \multicolumn{2}{|l|}{$\begin{array}{l}\text { Outer Membrane Vesicle } \\
\text { ELISA B:4:P1.19,15 } \\
\text { Vaccine Strain }\end{array}$} \\
\hline & & $n$ & $\begin{array}{l}\text { \% Seroconversion } \\
(95 \% \mathrm{CI})\end{array}$ & $\mathrm{n}$ & $\begin{array}{l}\text { \% Seroconversion } \\
(95 \% \mathrm{CI})\end{array}$ \\
\hline $\begin{array}{l}\text { Controlled, using Cuban } \\
\text { experimental BC vaccine }\end{array}$ & $\begin{array}{l}\text { Children } \\
\text { (aged 6-12 years) }\end{array}$ & 27 & $42(22-61)$ & 26 & $58(34-81)$ \\
\hline $\begin{array}{l}\text { Controlled, randomized, } \\
\text { double-blind }\end{array}$ & $\begin{array}{l}\text { Children-Adolescents } \\
\text { (aged 10-16 years) }\end{array}$ & 109 & $57(47-66)$ & 838 & $75(72-78)$ \\
\hline $\begin{array}{l}\text { Immunogenicity in } \\
\text { at-risk group }\end{array}$ & $\begin{array}{l}\text { Adults } \\
\text { (aged 18-29 years) }\end{array}$ & 60 & $78(73-82)$ & 60 & $48(43-53)$ \\
\hline $\begin{array}{l}\text { Controlled, randomized, } \\
\text { double-blind }\end{array}$ & $\begin{array}{l}\text { Adults } \\
\text { (aged 19-23 years) }\end{array}$ & 188 & $50(47-53)$ & 194 & $58(56-61)$ \\
\hline
\end{tabular}

Cl: Confidence Interval

Source: Registro Médico Sanitario VA-MENGOC-BC ${ }^{\circledR}$, Finlay Institute, Havana, Cuba a significant increase in the Immunoglobulin G (IgG) response and bactericidal activity in vaccinees.[23] As a complement to this study, the authors also reported the results of humoral immune response to $\mathrm{C}$ polysaccharide in children aged 1-5 years, from a region in the same Department of Antioquia.[24] Here, they concluded the immune response stimulated by vaccine $\mathrm{C}$ polysaccharide was high and the immunity level for both components was satisfactory in terms of intensity and protective capacity.

Pérez et al. have studied erologous strains of serogroup B in sera of vaccinees, using the Serum Bactericide Assay. Tappero et al.[22] also report a bactericidal activity response in serum samples of Chilean children vaccinated with VA-MENGOC-BC ${ }^{\circledR}$. Another report by Morley et al.[29] at Saint Mary's Hospital, London, demonstrates an induced immune response against the vaccine strain and other serogroup B heterologous strains, using WBBA.

In a clinical trial in Rio de Janeiro, Brazil assessing an anamnesic response, the persistence of specific antibody levels was observed in children vaccinated with VA-MENGOC-BC ${ }^{\circledR}$ 4 years earlier. The study compared the results of the assessment of bactericidal activity and specific antibody levels of the vaccinated child population of the Rio de Janeiro Municipality and the child population of Campos Municipality, Río de Janeiro State, which received its first vaccination with the Cuban vaccine for this trial, since that population had not been previously immunized with VAMENGOC-BC $®$. A remarkable difference was observed between SBA and ELISA results in participants who had been vaccinated 4 years earlier, showing higher antibody levels than those from the Campos population who had been vaccinated for the first time (priming vaccination). These results demonstrate an anamnesic response in the group from the Rio de Janeiro Municipality. The global Arithmetic Mean of the results of ELISA in the children of the Rio de Janeiro Municipality was significantly higher $(p<0.01)$ than that of children of the Campos municipality. [unpublished data]

Echeverry et al. published the results of a study in adults and children vaccinated with VA-MENGOC-BC ${ }^{\circledR}$ in the Department of Antioquia, Colombia, which evaluated the humoral response to serogroup $B$ protein components using SBA and ELISA. Results led to the conclusion that the vaccine caused
Table 2: Immune Response Induced by the C Component of VA-MENGOC-BC ${ }^{\circledR}$

\begin{tabular}{|c|c|c|c|}
\hline \multirow[t]{2}{*}{ Design (Country) } & \multirow[t]{2}{*}{ Group } & \multicolumn{2}{|c|}{$\begin{array}{l}\text { Serum Bactericidal Assay } \\
\text { C11 Vaccine Strain }\end{array}$} \\
\hline & & N & $\begin{array}{c}\% \text { Seroconversion } \\
(95 \% \mathrm{Cl})\end{array}$ \\
\hline $\begin{array}{l}\text { Non-controlled, experimental } \\
\text { (Colombia) }\end{array}$ & $\begin{array}{l}\text { Children } \\
\text { (aged 1-5 years) }\end{array}$ & 142 & $88(82-93)$ \\
\hline \multirow{2}{*}{$\begin{array}{l}\text { Non-controlled, experimental } \\
\text { (Ukraine, Russia, Belarus) }\end{array}$} & $\begin{array}{l}\text { Children } \\
\text { (aged 5-11 years) }\end{array}$ & 46 & $74(61-87)$ \\
\hline & $\begin{array}{l}\text { Adolescents } \\
\text { (aged 12-18 years) }\end{array}$ & 18 & $67(45-89)$ \\
\hline $\begin{array}{l}\text { Non-controlled, risk group } \\
\text { (Cuba) }\end{array}$ & $\begin{array}{l}\text { Young adults } \\
\text { (aged 20-22 years) }\end{array}$ & 54 & $78(67-89)$ \\
\hline $\begin{array}{l}\text { Controlled, randomized, } \\
\text { double-blind (Iceland) }\end{array}$ & $\begin{array}{l}\text { Young adults } \\
\text { (aged } 15-20 \text { years) }\end{array}$ & 26 & $96(88-100)$ \\
\hline
\end{tabular}

Cl: Confidence Interval

Source: Registro Médico Sanitario VA-MENGOC-BC ${ }^{\circledR}$, Finlay Institute, Havana, Cuba 
In conclusion, it can be affirmed that studies to assess immune response of VA-MENGOC-BC ${ }^{\circledR}$ vaccine have demonstrated that it confers adequate immunity against $B$ and $C$ meningococci, with long-term persistence.[31]

\section{VACCINE EFFICACY AND EFFECTIVENESS}

In 1987, a Phase III efficacy trial for VA-MENGOC-BC ${ }^{\circledR}$ was conducted. It was a controlled, double-blind, randomized trial, with the participation of 106,251 boarding school students, aged10-16 years, using a 2-dose schedule with 6-8 week interval.[12] The design was reviewed by specialists from the Center for Biologics Evaluation and Research, Bethesda, Maryland, and the Centers for Disease Control and Prevention (CDC), Atlanta. The trial was conducted in the 7 Cuban provinces with the highest incidence of the disease and lasted 16 months. The estimated efficacy was 83\% (Table 3). In studies to evaluate the impact of vaccination in Cuba at the beginning of the mass vaccination campaign in 1989 , a remarkable decrease in incidence of the disease in children aged $<6$ years was observed in provinces vaccinated, providing practical evidence of vaccine effectiveness in controlling the disease in the child population.[13,14]

An article on the epidemiological impact of vaccination in Cuba by Dr Antonio Pérez Rodríguez, of the Pedro Kourí Tropical Medicine Institute, compares the incidence of invasive meningococcal disease before (1984 to 1988) and after (1989 to 1994) the national immunization campaign with VAMENGOC-BC ${ }^{\circledR}$. The study showed that Incidence Density in the period before vaccination (ID $>8.8 / 10^{5}$ person-year) was higher than in the post-vaccination period (ID $<6.5 / 10^{5}$ person-year). Between 1989 and 1990, there was a decrease in Incidence Density (ID) in the following age groups: children aged <1 year; children aged 5-9 years; children aged 10-14 years; adolescents aged 15-19 years; and adults aged 50-54 years. ID comparison showed a decrease of Invasive Meningococcal Disease (IMD) in all municipalities during the postvaccination period. Those findings demonstrate the epidemiological impact of VA-MENGOC-BC ${ }^{\circledR}$ vaccination, as a reduction in morbidity of meningococcal disease in Cuba is observed.[15]

Martínez et al.[32] made an important and essential contribution to a better epidemiological understanding of meningococcal disease in Cuba and the impact of VA-MENGOC-BC ${ }^{\circledR}$ vaccination, by characterizing $N$. meningitidis strains isolated from healthy carriers during a 20-year period (1982 to 2002), including the preepidemic stage and the period of systematic and stable VAMENGOC-BC ${ }^{\circledR}$ vaccination starting in 1991 (post-epidemic). During the post-epidemic stage there was a significant decrease in the epidemic strain (B:4:P1.19,15:L3,7,9) among carriers, a total absence of $N$. meningitidis serogroup $C$ strains, and a predominance of non-epidemic-generating strains.

Other clinical trials estimating vaccine effectiveness have been carried out, such as a case and control study reported by de Moraes et al.[16] based on a prospective efficacy study carried out in Sao Paulo, Brazil, from June 1990 to June 1991, in which a $74 \%$ efficacy was estimated for children aged $>4$ years. The same study found the vaccine's protective efficacy was equivalent in patients in which the $N$. meningitidis isolates had the same serotype and subtype of the vaccine strain as those in which the isolates were serologically different. Only $51 \%$ of the isolated strains were similar to the vaccine strain. In their conclusions, the authors suggest that the vaccine can confer protection against serogroup B strains that differ from the vaccine strain in both serotype and subtype.

Cross-protection conferred by VA-MENGOC-BC ${ }^{\circledR}$ against heterologous serogroup $B$ strains (different serotypes and subtypes) has been a controversial issue since the vaccine was first used in countries such as Brazil, where circulating strains differ from the vaccine strain. In vitro results obtained by SBA and WBBA against heterologous strains show diverse crossreactivity, suggesting possible vaccine protection against outbreaks produced by those heterologous strains.

The OMV of $N$. meningitidis serogroup $B$, the active pharmaceutical ingredient of VA-MENGOC-BC ${ }^{\circledR}$, are complex structures. They contain Class 1 protein or Porin A (PorA) antigen, identified as the main inducer and target of bactericidal antibodies,[1] as well as a variety of membrane proteins, such as PorB, Opa, Opc, Tbp, NspA, high molecular weight proteins, and others[33] that are also considered interesting antigens, some of which are conserved in strains of various serotypes and subtypes. As Pérez et al. suggest,[30] other immune response effector mechanisms - in addition to bactericidal antibodies - can play an important role contributing to protection against strains differing from the vaccine strain.

A Cuban-Brazilian Commission estimating the impact of vaccination in several Brazilian states found an immediate decrease in the number of cases in the vaccinated population according to epidemiological data compiled.[17] Also in Brazil, Costa et al.[18] review several studies conducted in Rio de Janeiro and Santa Catarina, where vaccine efficacy ranged from $78 \%-82 \%$ in children aged $>48$ months; $62 \%-69 \%$ in those aged $24-47$ months; and $47 \%-55 \%$ in children aged $<24$ months. Other articles discussing results of the vaccine's use in Brazil conclude that the experience with the Cuban meningococcal vaccine was highly favorable in epidemic situations. [19]

An evaluation of the vaccine's effectiveness carried out in Itaguí, Colombia, and published by Galeano and Echeverry, re-

Table 3: Results Obtained from a VA-MENGOC-BC ${ }^{\circledR}$ Phase III Clinical Trial Conducted in Seven Cuban Provinces

\begin{tabular}{|l|c|c|c|}
\hline Group & $\begin{array}{l}\text { Number } \\
\text { Contracting } \\
\text { Illness }\end{array}$ & $\begin{array}{l}\text { Total No. of } \\
\text { Volunteers } \\
\text { (10-16 years) }\end{array}$ & $\begin{array}{l}\text { Attack Rate } \\
\text { per 100,000 } \\
\text { pop. }\end{array}$ \\
\hline Vaccinees & 4 & 52,966 & 7.6 \\
\hline Placebo & 21 & 53,285 & 39.4 \\
\hline
\end{tabular}

Source: Registro Médico Sanitario VA-MENGOC-BC ${ }^{\circledR}$, Finlay Institute, Havana, Cuba 
sulted in up to $98 \%$ effectiveness in a 4 -year follow-up study on vaccinees.[20]

\section{VACCINE DERIVATIVES}

Recent studies suggest that the OMV (also called proteoliposomes) from $N$. meningitidis $B$ - the active pharmaceutical ingredient of $\mathrm{VA}-\mathrm{MENGOC}-\mathrm{BC}^{\circledR}$ - and structures derived from them, known as cochleates, may become promising adjuvants for new vaccines and administration routes.[34-37]

\section{CONCLUSIONS}

VA-MENGOC-BC ${ }^{\circledR}$, administered in Cuba since 1989, has been shown to be a safe and effective vaccine for controlling epidemic outbreaks provoked by Neisseria meningitidis of serogroups $B$ and $C$. This is corroborated by the more than 55 million doses administered and the licensing of the vaccine in 15 countries. Currently, VA-MENGOC-BC ${ }^{\circledR}$ is the world's only commercially available vaccine against serogroup $B$ meningococcus, protected by three patents in 20 countries. $-1 /$ -

\section{REFERENCES}

1. Girard MP, Preziosi MP, Aguado MT, Kieny MP. A review of vaccine research and development: meningococcal disease. Vaccine. 2006;24:4692-4700.

2. WHO. Weekly epidemiological record, 77 th year. 2002; No. 40:329-40.

3. Valcárcel M, Rodríguez R, Terry H. La enfermedad meningocócica en Cuba: Cronología de una Epidemia. La Habana: ECIMED; 1991

4. Cuevas I, Casanueva V, Galindo MA, Armesto M, Domínguez F, Mesa I, Quintero D. Exploración de eventos adversos a VA-MENGOC-BC en tres municipios de Ciudad de La Habana. VacciMonitor. 1998;Año 8, No. 7:1-7.

5. Vacuna Antimeningocócica BC, VA-MENGOC $-\mathrm{BC}^{\circledR}$. Certificado de Inscripción No. 1133. Centro para el Control Estatal de la Calidad de los Medicamentos (CECMED). La Habana, Cuba; 1987.

6. Campa C, Sierra VG, Gutiérrez MM, Bisset G, García L, Puentes G, Sampedro MC, Sotolongo F, Xochitl LeRiverend E, Galguera M. Método para la obtención de una vacuna de amplio espectro protector contra Neisseria meninigitidis del serogrupo $B$ y la vacuna resultante. Patente Cubana CU 21888 A1;1989.

7. Campa C, Sierra VG, Gutiérrez MM, Bisset G, García L, Puentes G, Sampedro MC, Sotolongo F, Xochitl LeRiverend E, Galguera M. Method for obtaining a vaccine with wide protective range against group B Neisseria meningitidis, the resulting vaccine, gammaglobulin and transfer factor. European Patent EP 0301992; 1995.

8. Huergo CC, Sierra VG, Gutierrez MM, Bisset G, García L, Puentes G, Sampedro MC, Sotolongo F, Xochitl LeRiverend E, Galguera M. Method for obtaining a vaccine with wide protective range against group B Neisseria meningitidis, the resulting vaccine, gammaglobulin and transfer factor. US Patent No. 5,597,572; 1997.

9. Fundaçâo Nacional de Saúde. Ministerio da Saúde. Brasil. Manual de Vigilância Epidemiológica dos Eventos Adversos PósVacinaçâo; 1998.

10. Debbag R, Stambulian D. Evaluación de las reacciones adversas asociadas con la vacuna antimeningocócica BC. Informe preliminar sobre 8,117 vacunados. Rev Hosp Niños Buenos Aires. 1994;36:158-9.

11. Goyectche R, Pérez A, Morena G, Giacheto G, Pírez MC, Rubio I, Montano A, Ferrari A. Efectos adversos asociados a la vacuna anti- meningocócica VA-MENGOC-BC ${ }^{\circledR}$. Rev Med Uruguay. 2004;20:102-5.

12. Sierra VG, Campa C, Valcárcel M, García JL, Izquierdo L, Sotolongo F, Casanueva V, Rico O, Rodríguez $\mathrm{R}$, Terry H. Vaccine against group B Neisseria meningitidis: protection trial and mass vaccination results in Cuba. NIPH Annals. 1991;14:195-210.

13. Rico O, Almeyda L. Impacto de la vacunación con VA-MENGOC-BC en los niños menores de seis años en algunas provincias de Cuba. Rev Soc Argentina Pediatr Filial Córdoba. 1994;3(3): 65-8.

14. Almeyda González L, Rico Cordeiro O. Información general sobre la enfermedad meningocócica en Cuba: vacuna para su prevención y alcance. Rev Hosp Niños Buenos Aires. 1994;36:234-41.

15. Rodríguez AP, Dickinson F, Baly A, Martínez $R$. The epidemiologic impact of antimeningococcal $B$ vaccination in Cuba. Mem Inst Oswaldo Cruz. 1999;94:433-40.

16. de Moraes JC, Perkins BA, Camargo MCC, Hidalgo NT, Barbosa HA, Sacchi CT, Landgraf IM, Gattas VI, Vasconcelos HG. Protective efficacy of a serogroup B meningococcal vaccine in Sao Paulo, Brazil. Lancet. 1992;340:1074-8.

17. Comissâo Mista Brasil-Cuba. Relatório sobre a avaliaçâo da eficácia da vacina antimeningocócica $\mathrm{BC}$ de origem cubana. Informe Epidemiológico do SUS. 1994 Abril/Mai/Jun.

18. Costa EA, Amaral C, Juarez E. Eficacia da vacina antimeningocócica (VA-MENGOC-BC ${ }^{\circledR}$ ) nas condiçoes de uso no Brasil, no periodo 1989/90. CENEPI, Informe Epidemiológico do SUS. 1994 Abr/Mai/Jun.

19. Noroña CP, Baran M, de Araujo CC, Ocampo AT, Torres G, Sobral GR, de Souza R, dos Santos AM, Ferreira MC. Epidemiología a doença meningocócica na cidades do Rio de Janeiro: modificaçes após vacinaçâo contra os sorogrupos B e C. Cad Saúde Públ, Rio de Janeiro. 1997;123(2):295-303.

20. Galeano A, Echeverry ML. Efectividad de una vacuna antimeningocócica en una cohorte de Itaguí, Colombia. Bol Epidem Antioquia. 1995;20(2).

21. Perkins $B A$, Jonsdottir $K$, Briem $H$, Griffiths $E$, Plikaytis BD, Hoiby EA, Rosenqvist E, Holst $J$, Nokleby H, Sotolongo F, Sierra G, Campa C, Carlone GM, Williams D, Dykes J, Kapeczynski D, Tikhomirov E. Immunogenicity of two efficacious outer membrane protein-based serogroup B meningococcal vaccines among young adults in Iceland. J Infect Dis. 1998:177:683-91.
22. Tappero JW, Lagos R, Ballesteros AM, Plikaytis BD, Williams D, Dykes J, Gheesling LL, Carlone GM, Hoiby EA, Holst J, Nokleby H, Rosenqvist E, Sierra G, Campa C, Sotolongo F, Vega J, García P, Herrera J, Poolman JT, Perkins BA. Immunogenicity of 2 serogroup B outer-membrane protein meningococcal vaccines. A randomized controlled trial in Chile. JAMA. 1999;281:1520-7.

23. Echeverry ML, Malberty JA, Galeano LA Sotolongo F, Galguera MA, Montoya CM, Martínez O, Nerey MC, Camaraza MA, Bacallao J, Aguirre CA, Alzate LM, Sierra VG Campa C, Loaiza IB, Montealegre NA, Estrada E, Arroyave M, Restrepo E, Salazar BE. Respuesta inmune humoral a las proteínas de una vacuna antimeningocócica $B C$ en un ensayo realizado en Antioquia, Colombia. Bol Ofic Sanit Panam. 1995;118(4):56-8.

24. Echeverry ML, Malberty JA, Galeano LA, Sotolongo $F$, Galguera MA, Montoya CM, Blanco R, Martínez O, Aguirre CA, Alzate LM, Sierra VG, Campa C, Loaiza IB, Montealegre NA, Estrada E, Arroyave M, Restrepo E, Salazar BE. Respuesta inmune humoral al polisacárido capsular de Neisseria meningitidis serogrupo $C$ en un ensayo de vacunación antimeningocócica BC en Antioquia, Colombia. Bol Oficina Sanit Panam. 1995;118(4):73-87.

25. Goldschneider I, Gotschlich EC, Artenstein MS. Human immunity to meningococcus, I. The role of natural humoral antibodies. J Exp Med. 1969;129:1078-1307.

26. Boutriau D, Poolman J, Borrow JR, Findlow J, Diez J, Puig J, Baldó JM, Planelles V, Jubert A, Colomet J, Gil A, Levie K, Kervyn AD, Weynants V, Dominguez F, Barberá R, Sotolongo $\mathrm{F}$. Immunogenicity and safety of three doses of a bivalent meningococcal outer membrane vesicle vaccine in healthy adolescents. Clin and Vacc Immunol. 2007;14(1):65-73.

27. Ison CA, Anwar N, Cole MJ, Galassini R, Heyderman RS, Klein NJ, West J, Pollard AJ, Morley S, Levin R. Assessment of immune response to meningococcal disease: comparison of a whole-blood assay and the serum bactericidal assay. Microb Pathog. 1999;27 (4):207-14.

28. Granoff DM, Maslanka SE, Carlone GM, Plikaytis BD, Santos GF, Mokatrin A, Raff HV. A modified enzyme-linked immunosorbent assay for measurement of antibody responses to meningococcal $\mathrm{C}$ polysaccharide that correlates with bactericidal responses. Clin and Diagnostic Lab Immunol. 1998;5(4):479-85.

29. Morley SL, Cole MJ, Ison CA, Camaraza MA, Sotolongo F, Anwar N, Cuevas I, Carbonero M, Campa C, Sierra G, Levin M. Immuno- 
genicity of a serogroup $B$ meningocococcal vaccine against multiple Neisseria meningitidis strains in infants. Pediatr Infect Dis J. 2001;20:1054-61.

30. Pérez O, Lastre M, Lapinet J, Bracho G, Díaz M, Zayas C, Taboada C, Sierra G. Immune response induction and new effector mechanisms possibly involved in protection conferred by the Cuban anti-meningococcal BC vaccine. Infect Immun. 2001;69(7):4502-08.

31. Pérez $O$, Lastre $M$, Lapinet J, Pérez A, Díaz M, Zayas C, Batista A, Quintero Y, Aguiar F, Sánchez R, Sierra G. Long-lasting cellular immune response in babies, children, and preteenagers vaccinated with a proteoliposome based anti-meningococcal BC vaccine. Immunol. 2001;20(4):177-83.

32. Martínez I, Sierra G, Núñez N, Izquierdo L, Climent $Y$, Mirabal M. Caracterización de cepas de Neisseria meningitidis aisladas de portadores en Cuba durante 20 años. Rev Cub Med Trop. 2006;58(2):1-17.

33. Uli L, Castellanos L, Betancourt L, Domínguez F, Barberá R, Sotolongo $\mathrm{F}$ et al Outer membrane vesicles of the VAMENGOC-BC ${ }^{\circledR}$ vaccine against serogroup $B$ of Neisseria meningitidis: analysis of protein components by two-dimensional gel electrophoresis and mass spectrometry. Proteomics. 2004;6:3389-99.
34. Rodríguez T, Pérez O, Ménager N, Ugrinovic $\mathrm{S}$, Bracho G, Mastroeni P. Interactions of proteoliposomes from serogroup B Neisseria meningitidis with bone marrow-derived dendritic cells and macrophages: adjuvant effects and antigen delivery. Vaccine. 2005;23:131221.

35. Pérez O, Bracho G, Lastre M, Mora N, del Campo J, Gil D, Zayas C, Acevedo R, González D, López JA, Taboada C, Solís RL. Novel adjuvant based on a proteoliposomederived cochleate structure containing native lipopolysaccharide as a pathogen-associated molecular pattern. Immunol Cell Biology. 2004;82:603-610.

36. Pérez O, Bracho G, Lastre M, Zayas C, González D, Gil D, del Campo J, Acevedo R, Taboada C, Rodríguez T, Fajardo ME, Sierra G, Campa C, Mora N, Barberá R, Solís RL. Proteoliposome-derived cochleate as an immunomodulator for nasal vaccine. Vaccine. 2006;24S2:S2/52 -S2/53.

37. Pérez O, Lastre M. Cabrera O, del Campo J, Bracho G, Cuello M, Balboa J, Acevedo R Zayas C, Gil D, Mora N, González D, Pérez R, González E, Barberá R, Fajardo EM, Sierra G, Solís RL, Campa C. New vaccines require potent adjuvants like AFPL1 and AFCo1. Scand J Immunol. 2007;66:271-7.

\section{THE AUTHORS}

Franklin Sotolongo Padrón, (Corresponding Author), Second Degree Specialist in Microbiology, Executive Director, Finlay Institute, Havana, Cuba; fsotolongo@finlay.edu.cu

Concepción Campa Huergo, Pharmacist/ Biochemist, President-General Director, Finlay Institute

Victoria Casanueva Gil, Second Degree Specialist in Epidemiology Scientist, Medical Affairs, Commercialization Vice-President, Finlay Institute

Esther María Fajardo Díaz, Biologist/ Biochemist, Vaccine Adviser and International Relations, Finlay Institute

Iván Edelberto Cuevas Valdespino, Second Degree Specialist in Epidemiology, Scientist, Medical Affairs, Commercialization VicePresident, Finlay Institute

Noel González Gotera, Scientific Editor, SELSEL and VPI-INFO Internal Bulletins. Member of the Editorial Board of VacciMonitor, Research Vice-President, Finlay Institute

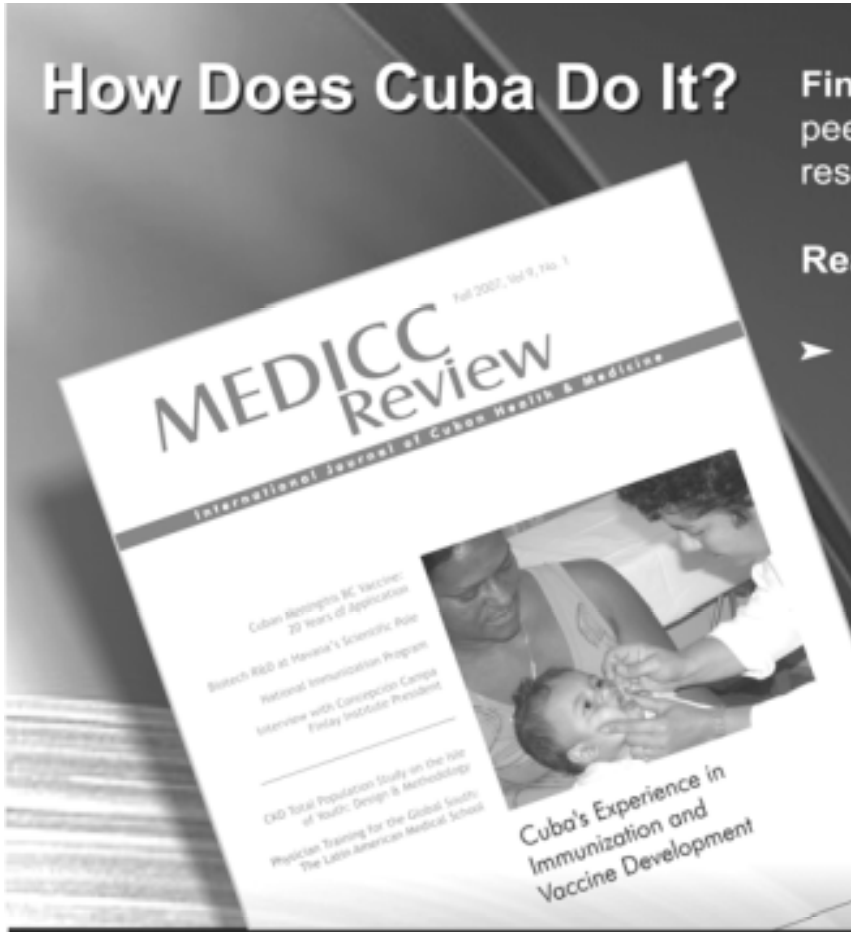

\section{Subscribe today!} Special introductory offers apply
Find out. Subscribe to MEDICC Review, the only English peer-reviewed journal featuring original Cuban medical research, latest health data and outcomes.

\section{Readable and reliable, MEDICC Review brings you:}

- Original articles by Cuban scientists in all fields of medicine and population health, internationally peerreviewed

- Exclusive interviews with leaders in Cuban health policy, research and clinical medicine

- Facts and features on Cuban international health programs

- MEDICC Review online with premium value-added content 